\title{
Elitist, Inequitable and Exclusionary Practices: A Problem within Ontario French Immersion Programs? \\ A Literature Review
}

\author{
Lauren Delcourt \\ University of Ottawa
}

The 2013 Ontario French Second Language (FSL) Curriculum emphasizes inclusivity and bilingualism; however, many students are recommended to opt out of French Immersion (FI). The opting-out of students may support the strengthening of the program by establishing a reputation of success, but how does it affect the withdrawn child? Are FSL programs using best practices to support all learners equitably, or catering to the elite students as a result of misconceptions, lack of resources and professional training? To address these questions, an exploratory and focused literature review of Canadian publications, Ministry of Education documentations and global articles on the topic of bilingualism was conducted, focusing on the works of Genesee (2007) and Baker (2006) on natural language acquisition, Arnett and Mady (2017) on teachers' and parents' perspectives, and Gour (2015) and Wise (2012) who report on misconceptions regarding second language education. Emerging trends indicate that elitist practices and unequal access to FSL programs remain a prominent issue in Ontario classrooms. With the understanding that students with learning disabilities (LDs) can succeed in the FI program, removing these learners may in turn, be a disservice to their overall learning. Findings presented in this paper support the need to examine how learners' abilities are being perceived by educational professionals to provide the necessary tools and supports for success, appropriate training to mitigate misconceptions, as well as retain a reputation for success in FSL programs through equitable means. Acknowledging such discrepancies between what serves as best teaching practice and making it possible in the classroom is necessary to reduce excuses of unpreparedness to meet students' diverse needs and initiate reflection and training programs that prepare teachers to teach inclusively to all.

Keywords: French second language, inclusive, French immersion, learning disabilities, language acquisition, bilingual 


\section{ACTES DU SJPD-JPDS PROCEEDINGS, 2018, VOL. 2}

Le programme ontarien de Français Langue seconde (2013; FLS) que suivent les élèves en immersion focalise sur l'inclusion et le bilinguisme. Or, des intervenants du milieu scolaire encouragent plusieurs étudiants à quitter l'immersion française. Cet abandon préserve possiblement la réputation de succès attribué à l'immersion, mais de quelle manière cet abandon affecte-t-il l'étudiant qui abandonne? Le programme FLS s'inspirent-ils de pratiques éprouvées de manière à garantir un traitement équitable pour tous les étudiants, ou plutôt, s'emploie-t-il à répondre aux besoins des étudiants performants dus à des conceptions erronées, aux manques de ressources ainsi que de formation professionnelle. Pour répondre à cette question, une revue de littérature a été produite, de manière exploratoire et focalisée sur des documents produits au Canada, notamment par les ministères d'éducation, ainsi que des articles généraux au sujet du bilinguisme, avec une emphase particulière pour les travaux de Genese (2007) et Baker (2006) portant sur l'acquisition naturelle d'une langue, ceux d'Arnett et Mady (2017) au sujet des perspectives parentale et estudiantine, ainsi que les travaux de Gour (2015) et Wise (2012) qui offrent une revue des conceptions erronées ayant trait à l'éducation aux langues secondes. Des tendances émergentes issues de cette revue de littérature indiquent que l'emploi de pratiques élitistes ainsi que d'accessibilité inéquitable est des enjeux important dans les classes en Ontario. Étant donné que les étudiants avec des difficultés d'apprentissage peuvent réussir en classe d'immersion, extraire ces étudiants de l'immersion peut en retour être contre-productif à leur apprentissage. Les résultats présentés dans cet article étayent le besoin d'examiner la manière dont les habilités des apprenants sont perçues par les professionnels de l'éducation, de manière à offrir les outils nécessaires pour assurer le succès, la formation, ainsi que pour contrer leurs conceptions erronées en regard du programme de FLS à travers des moyens équitables. Reconnaître l'écart entre les pratiques souhaitables et ce qui survient en salle de classe est nécessaire pour réduire les manques de préparation quant à la prise en compte des divers besoins des étudiants ainsi que pour initier des programmes de réflexion et de formation pour préparer les enseignants à enseigner l'inclusion pour tous.

Mots-clés: Français langue seconde, inclusion, immersion française, difficultés d'apprentissage, bilinguisme

Many parents have been invited into a parent-teacher conference to hear a general message expressing how their child is struggling in the French Immersion (FI) program and that it might be better to move the child to the regular English stream in order to reduce the child's anxiety and support the acquirement of expected grade-level literacy and numeracy skills. 
Despite the well-documented success of FI programs in Canada, with 428,625 (Statistics Canada, 2017a) students enrolled in public elementary and secondary FI programs in the 2015-2016 school year, a percentage of those students opt out of FI. In the 2016-2017 school year, the Ontario Ministry of Education (OME; 2017) reported that 8,871 grade two students were enrolled in French language programs, however an increasing attrition rate over the academic years produced a decrease of $22 \%$ of students by grade eight, with only 6,850 learners enrolled in French language programs.

The school system needs to develop alternatives for parents who have come to terms with the reality that their child may not be succeeding as easily or quickly in the FI program. Providing parents a single alternative option to switch the child into the regular English program is often presented as a positive solution that would be best for the child since it would reduce demands and allow them to develop in the areas of concern. Parents coming to terms with the awareness that their child is struggling and that an alternative is being provided may feel encouraged and persuaded by educational professionals to withdraw their child from FI. However, parents are encouraged to think openly and critically about their options, as each situation is unique.

The decision to withdraw a child certainly isn't easy for many parents as bilingualism in Canada has been given such significance over the years and the FI program is commonly known to provide strong second language proficiency. High enrollment in FI additionally supports the impression of a popular and successful program that is appealing to many. While the program accepts all students without any form of entry exam, there remains the possibility of withdrawal, which may perpetuate the idea that the FI program is privileged; or that, if one can be withdrawn, that French instruction is not as important as other subjects, such as English literacy and mathematics proficiency. Furthermore, it is noteworthy to consider how the withdrawal of struggling students may strengthen the FI program overall (by maintaining a higher average from the achievers), but is this a fair outcome for the learner? Were the struggling student's needs met prior to the decision to withdraw them? Furthermore, despite the commonly recognized advantages of learning French in Ontario (e.g., employment opportunities, positions with higher pay, better attention span, multitasking skills, networking and social opportunities), the means and methods of learning this language differ based on the educational context. A divide has developed as Core French classrooms fill with students with diverse learning needs (including those who have withdrawn from FI programs), while the FI classroom remains the ideal context for longterm language acquisition (Genesee, 2007), and consequently, achieves great recognition for their production of higher academic achievers. In an education system held to specific 


\section{ACTES DU SJPD-JPDS PROCEEDINGS, 2018, VOL. 2}

standards of inclusivity, critical reflection and intentional action on the parts of all stakeholders in the field of education in Ontario, is necessary to address this phenomenon within French Second Language (FSL) classrooms to ensure that all learners are accessing the highest quality education.

The first sign of inequality in FSL programs across Canada is that while some students are fortunate to study the language in its most ideal format through FI, others are excluded on the basis that their needs are incompatible with the goals of the FSL curriculum (Arnett \& Mady, 2010). Further, the inability of the current FSL program to meet the needs of all students contradicts the reality of other curricular programs that have found ways to adequately support students with diverse needs, even with incongruent content to be taught (Arnett \& Mady, 2010). Thus, studying the causes and effects regarding practices of exclusion in FSL programs becomes pertinent.

This paper reviews the literature pertaining to how and why elitist and inequitable FSL practices remain a prominent issue in Ontario by reviewing several common misconceptions regarding one's ability to acquire a second language (L2). The paper first examines the Ontario FSL curriculum for its mandate and emphasis on French second language learning and then reviews the role and structure of bilingual education in current Ontario classrooms. The present paper also investigates how streamlining and the existence of separate FSL programs in Ontario may support a hierarchical framework in schools, ultimately creating exclusivity that may result from limited support for students with learning difficulties and misconceptions regarding ability and acquisition of language.

\section{Methodology}

The process of reviewing research and publications for this paper first included researching from an initial question surrounding the idea of streamlining students. Specifically, the initial search focused on whether this conundrum regarding student success is either based on streamlining, which provides the ideal context for learning and leads to higher success rates (indicating that those who complete the program have learned advanced skills), or whether streamlining is ability-based, where success rates are based on the individual learners in the program (and where students already have within them the ability to succeed and the program supports the learner). This question lead to the idea that students are withdrawn in either case, but that the withdrawn students are, for the most part, those with exceptional needs or learning disabilities and those who are Englishlanguage learners. Further initial questions included whether everyone can learn a second 


\section{ACTES DU SJPD-JPDS PROCEEDINGS, 2018, VOL. 2}

language, whether exclusionary practices are being experienced in Ontario, as well as whether there are determined evidence in the literature upon which to base these outcomes.

Thought examining Ministry of Education documents, using personal teaching experience, speaking with teachers, parents and educational administrators, it became apparent that there is a sense of concern with regards to who can and cannot acquire a second language, how students with learning disabilities are (and are not) supported in today's schools, as well as a common expression of wanting more supports and resources available for all FSL learners. With an initial issue to examine, research was accumulated using search terms including: FSL exclusion, learning disabilities, language acquisition, bilingualism in Canada, and French Immersion.

While some literature on bilingualism and language learning presenting Canada-wide findings or internationally relevant research, such as Baker's (2006) Foundations of Bilingual Education and Bilingualism, were consulted, keeping research specific to the Ontario context was imperative to this literature review. The intention for this paper is to bring together relevant information regarding FSL education in Ontario in order to highlight important areas of concern for which the OME and individual school boards in the province should take note. Additionally, it serves to provide connections and support for teachers and parents when it comes to trying to provide best teaching practices that offer students meaningful and intentional decisions regarding their academic career that is based on research evidence as opposed to misconceptions. The intent is to connect research to practice and provide a basis for teachers and parents to think critically about learners' ability so that instruction is equitable and inclusive.

\section{FSL Ontario Curriculum}

The Ontario FSL Grade 1 through 8 Curriculum supports stipulations set by the Canadian Council of Ministers of Education (CMEC) within their Protocol for Agreements for Minority-Language Education and Second-Language Instruction (2009). This Protocol sets the "outcome frameworks" for primary student participation and the "maintenance, development, enrichment and/or evaluation of programs and innovative teaching approaches for second-language learning" (p. 5). Bilingual programs are acknowledged for their importance and, further, receive funding for FSL services from the Government of Canada (CMEC, 2009). Such funding should support the Ontario French as a Second Language Curriculum's overall slogan, as stated on the front cover of curriculum documents, to 


\section{ACTES DU SJPD-JPDS PROCEEDINGS, 2018, VOL. 2}

"support every child, [and] reach every student" (2013), which prefaces its document with the following claim:

Ontario elementary schools strive to support high-quality learning while giving every student the opportunity to learn in the way that is best suited to his or her individual strengths and needs. [...] The curriculum recognizes that the needs of learners are diverse and helps all learners develop the knowledge, skills, and perspectives they need to become informed, productive, caring, responsible, and active citizens in their own communities and in the world. (p. 3)

With strong emphasis on supporting the needs of all students, it is questionable that in practice struggling learners (i.e., those who have difficulty keeping up with their FSL classmates) withdraw to the English program. This trend is especially concerning despite the Ontario FSL curriculum's (OME, 2013) direct acknowledgement that "knowledge of an additional language strengthens first-language skills [and the] ability to speak two or more languages generally enhances cognitive development, as well as reasoning and creativethinking skills" (p. 7). The benefits further outlined in the curriculum include: increased mental flexibility, a better understanding of cultures, greater awareness of global issues, improved problem-solving skills, and expanded career opportunities (OME, 2013).

Any parent interested in registering their child in French immersion can do so if they complete an online application process. While it is not usually a first-come first-served process, schools do have caps on enrollment depending on number of classrooms and teachers. Late applications and those who are not randomly selected are placed on a waitlist. Students who are waitlisted may be placed upon confirmation of school classroom reorganization that takes place leading up to the following school year, may choose to attend a different school, or choose to remain on the waitlist and wait for an opening. Unfortunately, with the popularization of FI as the ideal method of instruction for bilingual learning, many school boards across the province, such as Guelph's Upper Grand District School Board (Hallett, 2017), are finding it challenging to keep up with the demand. Further, while English classrooms are reducing in size as FI rooms are overfilling with interest, the English rooms are being perceived as the program for students with higher needs, and specifically, for those who have needs that do not fit with those of the FI program. This divide is becoming alarming. Not only do those who withdraw from the program arguably lack the opportunity to expand their skills, but those who are unable to enter the program are also perceiving the connotations each program evokes. 


\section{ACTES DU SJPD-JPDS PROCEEDINGS, 2018, VOL. 2}

\section{Bilingualism}

There is a strong emphasis placed on second language (L2) acquisition in Canada. While the pertinence and benefits are commonly recognized for social and professional gain, bilingual education, according to Baker (2006), can be "a simplistic label for a complex phenomenon" (p. 192). Students are often subject to streaming at young ages, which is the practice of separating children based on age and or ability, causing a widening gap in classroom dynamics between the English regular program receiving Core French instruction and the Immersion Program. According to Baker (2006), bilingual education:

will facilitate national cohesion and cultural integration, and enable different language communities inside a country to communicate with each other [...]. For other people, bilingual education will create language factions, national disunity, and cultural and economic and political disintegration. Education has thus been conceived as both part of the solution and part of the problem of achieving national unity, achieving diversity or unity in diversity. (p. 374)

The complexity of bilingual education is recognized across Ontario classrooms as the province is home to a multilingual population with native English and French speakers, as well as immigrants from around the world. In an attempt to offer structure and meet the needs of diverse learners, opportunities are, arguably, simplified to a few options to meet provincially legislated mandates for learning French. Two of these options include the French Immersion Program and the Core French Program. The Core French program "is intended to provide children with a basic level of proficiency in French" (Lazaruk, 2007, p. 606) while the FI programs goes further than teaching just the language arts portion but uses French as the means of instruction for other subject areas, thus providing students a wider range of vocabulary and an active use of the language in order to acquire new knowledge in other areas. In having two options, however, the element of choice is presented as pathways for student success. Parents decide at the beginning of their child's academic career which program to enroll, each leading to different levels of second language mastery.

\section{Elitist Program}

A hierarchy is created with the existence of choice between the Core French and Immersion program. The question of who should and should not study FSL allows for an answer that may restrict one's access to learning an L2 altogether or deciding which program one should learn from. Arnett and Mady (2010) reference The Law Society of New Brunswick, 


\section{ACTES DU SJPD-JPDS PROCEEDINGS, 2018, VOL. 2}

as well as works by Ryan (2003) and Rushowy (2009), to highlight how this hierarchy of choice may lead to discrimination: "Since 2008, FI programs in several jurisdictions have come under scrutiny, including through legal actions, for their perceived discrimination against certain learner populations, including students with learning difficulties" (p. 20).

Despite the Core French classroom environment showing promise in appropriately supporting students with more complex learning needs (Arnett \& Mady, 2010), how FI and Core French programs differ in supporting all students should be examined by the OME, as well as whether an element of teacher belief remains that only select learners can succeed in FI classrooms. It may be the case that the school boards do not want to shine light on the lack of support offered to academically low-achieving students in FI, as this reality is based on limitations in staffing qualified French educators. In fact, the challenge of recruiting and retaining qualified FSL teachers across Ontario public schools has been relentless since the early 2000s (Ontario Public School Boards' Association, 2018). The growing gap between the increasing number of students enrolling in FSL programs and the availability of teachers is certainly problematic when the goal is to make FSL education a possibility for all. Alternatively, perhaps there are challenges with regard to confidentiality and ethics for parents to voluntarily share their experiences regarding the challenges and support (or lack thereof) offered to their child. Speaking up about an issue is challenging. Some parents may not want to expose how their child has struggled. For one parent, sharing the personal story was crucial in informing others of how her son struggled to be included in the FI program. (Mady \& Arnett, 2009). Due to having academic struggles, her son was excluded from a program that, in a time of celebrated inclusivity, should be accessible and beneficial to all.

Research over the years has attempted to establish how and why some students struggle in FI, as well as try to classify the precise difficulties that would hinder a student from succeeding in the program. Mady and Arnett (2009) outline three areas in which the educational experience of a student may be affected:

how the processes and policies shaping the identification/diagnosis of learning disabilities contradict the ideals of the inclusion movement, how the status often accorded to the FI program has deterred inclusive efforts, and what research on struggling students in FI does and does not reveal about the connection between student needs and classroom practice. (p. 37-38)

There are several factors that contribute to an overall sense of elitism, as only some students maintain their access to a strong bilingual program that lacks inclusion for all. These factors 


\section{ACTES DU SJPD-JPDS PROCEEDINGS, 2018, VOL. 2}

include: the complex nature of the paradox of increased enrollment in FSL programs while fewer qualified French teachers enter the workforce, the difficulty to cater to all learning needs in the classroom, the challenge for school boards to balance different FSL programs through Core and Immersion options that offer quite differing learning experiences and end results, as well as the inability to specify the characteristics of learning needs that prescribes a recommendation for withdrawal.

\section{Differing Pathways: Streamlining Students}

Streamlining students is a process by which students become grouped based on age, ability, interest, etc. In the case of second language education, students' trajectories follow different paths: either that of the French immersion program or the Core French program. Different views on streamlining exist from different educational and policy vantage points. Depending on the desired outcome and the stakes set for the success of students, the ministry of education, the teacher, the parent and the student may hold differing opinions. From one perspective, it is the initial promise of ability demonstrated at a young age that causes streamlining. For example, Mady and Arnett (2009) found through analysis of emergent skills in young students that "most of the children enrolled in the [FI] program had significantly higher scores on literacy measures than students who would enroll in the Core French language program [... and] children with observable behaviour problems were less likely to enroll in EFI than the other program options" (p. 44). The element of behaviour provides another consideration with regards to streamlining as students can be segregated based on ability or behaviour. Generally, problematic behaviour often indicates that a child is struggling in the classroom (Mady \& Arnett, 2009).

From another perspective, the FI program may develop stronger academic abilities within some students, and those who cannot keep up are advised to opt out. Streamlining based on ability gives attention, according to Mady \& Arnett (2009), "to those students who likely make the biggest academic gains within FI and strengthen its status as the best way to learn French in Canada, [... while] those whose test scores indicated a potential for struggle might be directed elsewhere" (p. 44). This is the case when Ontario students are withdrawn from the FI program and integrated into the Core French program.

Although educators prioritize student learning, various stakeholders, such as program FI administrators, the OME, school board representatives and parent council volunteers, often hold different agendas. If promoting the reputation of success of FI programs is the goal, streamlining would serve to increase overall success rates (e.g., a 


\section{ACTES DU SJPD-JPDS PROCEEDINGS, 2018, VOL. 2}

successful reputation of the FI program attracts more bright and high-achieving students). The successful reputation thus attracts students from predominantly middle- and uppermiddle class backgrounds (Wise, 2012) whose parents recognize the program as one that will better serve to prepare their child and offer advantages for the workforce. The FI program is further enhanced by those with a belief that it remains the ideal context for not only learning the second language but providing stronger aptitude for learning since the learning of other subjects is additionally taught in the second language. While the program is strong and is very successful in many ways, not every child is supported equitably in the program. This creates a form of segregation across socioeconomic backgrounds (Wise, 2012) of those enrolled in FI (based on access to schools offering the program, the availability of teachers qualified in the area, etc.), as well as discourages ESL learners who have immigrated to Canada based on the belief that learning English is already challenging enough (Wise, 2012). Streamlining students between two possible programs for second language acquisition, whether based on ability or promise, provides an illusion of hierarchy that could make one seem more promising. Those that get to maintain their place in the program continue to learn, while others are directed elsewhere. The result becomes that certain student populations are obtaining greater success in language acquisition than others.

\section{Exclusivity}

\section{Learning Difficulties}

Statistics Canada (2017b) reports that more than 1 in 10 youth, aged 15 to 24, have one or more disabilities; however, according to the Learning Disabilities Association of Ontario (ldao, 2018), "statistics on incidence rates can be particularly vulnerable to distortion or bias for a number of reasons" (n.p.). This is particularly problematic as a consensus on the definition of learning disabilities does not currently exist. This lack of a clear definition can lead to an inability to identify learning disabilities in the educational context. As Lyon et al. (2001) points out, the lack of consensus on a definition for learning disability makes it even harder to identify and ultimately follows a form of "wait to fail" model, where by the time a student's weaknesses are identified as part of a learning disability, it may be too late to apply interventions to make a significant difference in the child's experience. The reason why it unfortunately takes longer to identify a learning delay as a learning difficulty is often by virtue of the challenge of identifying whether the difficulty is language- or cognitive-specific. Additionally, when learning disabilities (LD) are hard to define, appropriate interventions and supports are consecutively challenging to develop. Therefore, in many cases, the suggestion of withdrawal arises. However, Arnett and Mady 


\section{ACTES DU SJPD-JPDS PROCEEDINGS, 2018, VOL. 2}

(2010) raise the important point that FSL programs should be held to the same standard as other educational programs by incorporating the means necessary to implement the mission statement set by the OME for inclusion across all learning programs.

Special education legislation in Ontario and across Canada ensures that each child has access to the general education curriculum, which ensures only a basic French language program (Mady \& Arnett, 2009). Even though FI is regarded as the most effective program for developing language proficiency (Genesee, 2007), it is often considered more of an enrichment program than a basic course of study (Mady \& Arnett, 2009), which prompts student withdrawal with the implication that FI can be of lesser importance when compared to other subject areas, such as English literacy and mathematics.

There is a consistent lack of special education programs and services provided in the FI setting (Wise, 2012). This illuminates a question of whether the recommendation to opt out is based on student ability or the capacity for the regular English stream to provide appropriate and effective support services where the FI stream does not. Wise (2012) highlights that students are withdrawn based on the claims that "(a) the educational needs of exceptional students will be better met in the English program, and (b) the provincial funding model does not permit a full range of special education programs and services in the FI context" (p. 179). In opposition, Wise (2012) asserts that "the first claim has never been substantiated, and the second is false" (p. 179). Yet, officially, no child is ineligible for the FI bilingual education program since there is not, and has never been, any provincial screening procedures that determines eligibility for enrolment in FI (Wise, 2012). Therefore, the misconceptions surrounding eligibility and proficiency require reflection and modification in order to become more inclusive of a wider range of students' needs.

Students who are withdrawn from the FI program often continue to struggle. Bruck (1978) found that:

If switched, [children] would have exactly the same problems in an English stream [and that] switching would be detrimental to the child's self-esteem: the child would be marked as not succeeding, would be separated from friends, and would have to readjust to a new social-educational system (p. 52).

Despite being further behind than their peers in English language development and possibly other subject areas since the instruction was previously in an L2 (Bruck, 1978; Lazaruk, 2007), the support they receive is "typically based on an understanding of the child's deficits, 


\section{ACTES DU SJPD-JPDS PROCEEDINGS, 2018, VOL. 2}

not his/her capabilities" (Mady \& Arnett, 2009, p. 41). This perspective, according to Mady and Arnett (2009), can be "pathognomonic, [... as it] views disability as a pathos that is not open to remediation and implicitly argues that strategies and supports will have minimal impact on a child's growth in the classroom" (p. 41). Furthermore, when students are withdrawn from the FI program and placed in the regular English stream with Core French, it is not always to their benefit either. In fact, downgrading to Core French programs may be an additional disservice to those with LDs since "many language-disabled children cannot cope with a typical [FSL] program (typically given for 20-40 minutes a day several times a week); [and ultimately,] leave school with almost no knowledge of French" (Bruck, 1978, p. 70). Bruck (1978) suggests that this problem is based on teaching methods (e.g., a great deal of memory work, repetition of language out of context, the learning of abstract rules), which do not favor to the strengths of students with learning disabilities. Arguably, these students are still receiving FSL instruction, though not as effective, it is in contradiction with the philosophy of inclusion, which emphasizes that all students can achieve success when appropriate supports are available. The lack of consensus of definition of learning disabilities and the fact that, for many students, the transition to the English Program with Core French is not beneficial, there becomes no evident reasons, as highlighted by Wise (2012), to deprive some students from a bilingual education.

\section{Pedagogy and Differentiation}

French Immersion is often regarded as an enrichment program (Mady \& Arnett, 2009) that goes beyond the basic level of study that is required. Thus, exclusion (the process that occurs when a student is denied access to participate) would exemplify through the inability to maintain a participator in a program that arguably doesn't meet the needs of that learner. However, if FI is viewed as a program that goes beyond the basic level of study and that Core French is really the minimum requirement, withdrawal from that program tends not to be viewed as a violation of the legal mandates regarding special education. While there may be validity in such logic, it is hard to reconcile that line of thinking with the current climate emphasizing differentiated instruction that is designed to cater to individual learning styles, paces, interests and strengths. Differentiation includes methods such as: grouping students based on ability or interest, designing lessons based on learning styles, adjusting lesson content to meet students' needs, providing additional resources, and adapting summative tasks/products to demonstrate learning to meet learner needs.

Teachers have the challenge and responsibility to meet every student's diverse needs. However, supporting all students requires appropriate resources. The "FI program has been 


\section{ACTES DU SJPD-JPDS PROCEEDINGS, 2018, VOL. 2}

at odds with students with special needs almost since its inception" (Mady \& Arnett, 2009, p. 43). With an ongoing lack of resources, support and strategies for differentiation to accommodate all learners, the noteworthy consideration becomes whether those who struggle should transfer to the English program and receive French instruction through the Core Program on the basis that it is the better choice for the student, or whether it is the result of the lack of resources and support systems for the learner in the FI program. Given that two options are available while supports are limited allows a perception that the FI program is, on some level, intended for the academic elite. This perception is further support by the fact that similar logic would not hold for other curricular content. For example, although science or math may be challenging for students, Mady and Arnett (2009) highlight that "when students experience academic challenges [...], they are not removed from those subjects. Supports are extended to the student with the goal of helping [him/her] succeed in the classroom" (p. 45). Unfortunately, it does not help in the case of French second language education that "there has been very little research on the kinds of support that can make immersion more inclusive" (p. 45). Until a change occurs to offer the supports and means necessary to provide differentiated pedagogy and instruction, students struggling with the material will continue the cycle of struggling and facing the decision to opt out of the FI program to the regular English stream, perpetuating these ideas of elitism and exclusion.

\section{Misconceptions}

According to the recent findings of Arnett and Mady (2017), "teacher candidates recommended core French as the best context for FSL students with LDs", a recommendation not based "in their experience or in the program's ability to have greater success with students with LDs, but due to its lesser demands" (p. 28). According to researchers (e.g., Arnett and Mady, 2017; Genesee, 2007), English Language Learners (ELLs), like students with learning difficulties, can succeed in the FI program when provided with the appropriate supports. Teacher education programs and professional development opportunities need to reflect this sentiment as well as recognize the misconceptions of student ability in order to incorporate into professional practice a drive and understanding that all children can succeed when they have access to the tools, patience and support necessary to do so. The following sections provide an overview of the literature regarding misconceptions about the ability of students with LDs and ELLs. 


\section{ACTES DU SJPD-JPDS PROCEEDINGS, 2018, VOL. 2}

\section{Ability}

According to Baker (2006), "some bilinguals actively speak and write in both languages (productive competence), [while] others are more passive bilinguals and have receptive ability (understanding or reading)" (p. 3). Regardless of type, bilingualism can begin during infancy or during later developmental years. Language acquisition is a process that develops differently from one to another depending on various factors. Baker (2006) notes that for many individuals, language acquisition is generally more rapid for older students in a formal classroom, while those who learn at an early age and continue progressing in developing the language for a number of years "tend to show higher proficiency than those who start to learn the second language later in their schooling" (p. 125). An individual's age, however, correlates more strongly with the learning situation than the individual's ability to acquire the language (Baker, 2006). Therefore, beginning the acquisition of second language learning is likely to be more successful when an individual begins acquiring early and continues learning throughout their academic schooling experiences. This ideal case correlates to the French Immersion program that is offered in Ontario schools that allows students to begin acquiring French as a second language in Kindergarten and to continue throughout their secondary years of education.

\section{Negative Impacts on L1 from Learning an L2}

Historically, a popular belief has existed that L2 acquisition would negatively affect a child's L1, especially when most FI students receive little or no instruction in English prior to Grade 3 or 4 . Research findings publicized by Swain in 1974, summarized by Lazaruk (2007), states that although "students' English reading and spelling skills were compromised in comparison to children who had received instruction in English[,] once formal English studies are introduced [...] students make rapid progress in their English reading and writing skills" (p. 613). In practice, these results, as reviewed by Turnbull, Lapkin and Hart (2001), is often recognized by lower grade 3 English literacy scores on Ontario provincial tests completed by students in the FI program, which become significantly higher, even more successful than students in the English program, a few years later when students complete the provincial tests in Grade 6. Lazaruk (2007) further highlights Paradis' neurolinguistic theory of bilingualism (2004) to offer the explanation that:

bilinguals understand each language directly, just as monolinguals do. Rather than translating to themselves in their L1 what they have heard or said in their L2, bilinguals organize their mental representations in accordance with either the 


\section{ACTES DU SJPD-JPDS PROCEEDINGS, 2018, VOL. 2}

patterns of the first language or those of the second, depending on which is appropriate. Bilinguals thus have the ability to adopt two perspectives, an advantage that enhances general mental capacity and supports alternative ways of considering the same information. (p. 621)

The mental capacity that is developed for language acquisition appears to enhance the neurological ability to complete literacy activities and questions with accuracy.

\section{Immigrants and English Language Learners (ELLs)}

Arnett and Mady (2017) highlight that "in some school districts, [ELLs] were either overly restricted from studying FSL [... referred to as an exemption] or allowed to enroll in the programs without any noted concerns about their participation" (p. 19). ELLs thus enter the Ontario education program and choose to either follow the recommendation to register in the English stream, with some receiving exemptions from the program altogether, despite the OME's mandatory French credit necessary for graduation. The rationale, drawn by Arnett and Mady (2017), is that learning two languages at the same time would be far too difficult or impossible. Instead, the belief is that ELLs should first acquire the more prevalent English language. However, it is interesting to examine the research done in this area, such as that of a study completed in Alberta by Swain, Lapkin, Rowen and Hart (1990), which compared assessment in of 200 immigrant grade 8 students who started FI in grade 5 to anglophone students in the regular English program. Their results indicated that the anglophone students were not as successful as the immigrant students, which can be supported, as suggested by Lazaruk (2007), with the explanation that an individual's first language skills contribute to the development of second language skills.

\section{Conclusion}

Bilingual abilities are beneficial to those living and working in Canada and the education system is witnessing the popularity in FSL programs across the country and working to adapt its programming and pedagogies to accommodate the diversity of learners in the classrooms. Canadian education has advanced in its beliefs surrounding language acquisition to acknowledge that learning an L2 would not complicate or delay overall language learning. However, language teachers' role remains complex in that it needs to provide equality and equity of access to learning for all while supporting and celebrating difference and uniqueness of each individual learner. Further responsibilities include leading each unique learner toward a common goal, in this case, that of acquiring second 


\section{ACTES DU SJPD-JPDS PROCEEDINGS, 2018, VOL. 2}

language to a degree to which each individual can be successful in their lives. The misconceptions that exist surrounding language acquisition and FSL teaching thus lead to possible ineffectiveness, exclusion and creating an illusion of FSL as inferior, or less important, than other subjects.

The Ontario Curriculum (2013) recognizes the advantages of bilingualism and states its support for FSL programs, yet students are withdrawing from the FI program increasingly every year as they move through the grade levels in Ontario. Thus, the misconceptions surrounding FSL education and the opportunity to learn an L2 should ultimately be based, in agreement with Genesee (2007), on the overall happiness of the student in the program, as well as whether the learner is progressing toward acquisition, regardless of the learner's pace of learning. If a student is having difficulties in the areas of language, reading or other academic subjects taught in the FSL context, then an assessment must be done to determine the supports necessary to encourage and provide access to learning in a way that not only recognizes academic progress, but overall well-being and potential for success across the subject areas. There are some students who find learning in a second language too much of a burden and feel their sense of well-being, confidence and happiness beginning to fall, and in these cases, it is important to recognize the learner as human and make a decision that supports the child most meaningfully. However, those who are happy in the program despite their difficulties, should be encouraged and effectively supported as they have the capacity to learn.

This paper aimed to highlight and connect important issues facing French second language education in Ontario. Exclusionary practices manifest in many forms including: lack of supports and resources provided to teachers, misconceptions not addressed regarding language acquisition, as well as the challenge of schools to keep up with the high demand for bilingual education. An elite perspective of the FI program in the elementary school context emerged, indicating that positive and intentional change must take effect in order to offer all students access to equitable and inclusionary education. Considering the misconceptions surrounding this topic, it is important for educational professionals to reflect on their practice and to acknowledge their own biases. Further, it is also beneficial to continue research into developing a deeper understanding of how students differ in language proficiency acquisition, as well as developing models of identification and intervention for those who are struggling.

Although the present literature review provided a window into the education field's current knowledge on Ontario's FI programs, questions inevitably remain, such as: which 


\section{ACTES DU SJPD-JPDS PROCEEDINGS, 2018, VOL. 2}

factors are unique to second language learning difficulties? How can resources be developed and shared that would scaffold and differentiate support to students struggling specifically in FI? Which essential elements must be incorporated into teacher training to clarify and define language acquisition and proficiency development to prepare teachers to support all learners inclusively? Further recommendations to benefit equitable FSL instruction could include, for instance, having a designated professional to offer unbiased input into whether it is in a child's best interest to withdraw from FI. This way, an objective perspective could provide a basis for validating whether a child truly is not a good candidate for learning in a FI context where all subjects are taught in the second language.

It is not only the action of educational professionals and researchers that makes change possible. Rather, it must be acknowledged that "inaction on the part of multiple FI stakeholders (e.g. government officials, parents, and educators) to move toward more inclusionary practices constitutes a 'conspiracy' of silence which limits access to FI programs to the English-speaking academic elite from higher socioeconomic backgrounds" (Wise, 2012, p. 178). Discriminatory practice evolves from the lack of change in the current FSL program that is not presently able to successfully provide equitable access to special education programs and services to all. Students enter the classroom with a range of backgrounds, interests and needs and are entitled access to education stipulated by the provincial ministry of education, which currently stipulates an importance for second language French instruction.

As authors and researchers, Wise, Mady and Arnett, strongly advocate (through their numerous publications and initiatives) for equity in FSL education in Ontario. This paper intends to provide an additional motivation for change in making equity possible in every school across the province. Inaction must be replaced with directed action to gather resources and support for differentiation and inclusive practices for all students. The excuse that "FSL teachers are unprepared to meet the needs of students with diverse learning needs" (Arnett \& Mady, 2010, p. 32) must end in order to alleviate the sense of elitism and exclusion associated with the FI program in Ontario. 


\section{ACTES DU SJPD-JPDS PROCEEDINGS, 2018, VOL. 2}

\section{References}

Arnett, K., \& Mady, C. (2017). Core or immersion? Canadian French-second-language teacher candidates' perceptions and experiences of the best and worst program options for students with learning difficulties and for English language learners. Exceptionality Education International, 27(1), 17-37.

Arnett, K., \& Mady, C. (2010). A critically conscious examination of special education within FSL and its relevance to FSL teacher education programs. The Canadian Journal of Applied Linguistics, 13(1), 19-36.

Baker, C. (2006). Foundations of bilingual education and bilingualism. (4th ed.). Clevedon, UK: Multilingual Matters.

Bruck, M. (1978). The Suitability of Early French Immersion Programs for the Language-Disabled Child. Canadian Journal of Education, 3(4), 51-72.

Council of Ministers of Education, Canada. (2009). Protocol for agreement for minority language education and second-language instruction, 2009-2010 to 2012-2013 between the Government of Canada and the Council of Ministers of Education, Canada. Her Majesty the Queen in Right of Canada. Retrieved from https://www.cmec.ca/Publicat ions/Lists/Publications/Attachments/211/protocol-for-agreements-2009-2013.pdf

Genesee, F. (2007). French immersion and at-risk students: A review of research evidence. Canadian Modern Language Review, 63(5), 655-687.

Gour, R. (2015). Engagement or despondence? Ontario middle-school core French teachers' perceptions of and experiences with the 2013 Ontario French as a second language curriculum (Doctoral dissertation). Retrieved from https://tspace.library.utoronto.ca/bitstr eam/1807/70346/1/Gour_Rochelle_201511_MA thesis.pdf

Hallett, D. (2017). Demand for French Immersion in Guelph far exceeds board cap. Guelph Mercury Tribune. Metroland Media Group Ltd. Retrieved from https://www.guelphmercury.com/news-story/7101466-demand-for-french-immersion-inguelph-far-exceeds-board-cap/

Halsall, N. D. (1994). Attrition/retention of students in French immersion with particular emphasis on secondary school. Canadian Modern Language Review, 50(2), 312-345. 


\section{ACTES DU SJPD-JPDS PROCEEDINGS, 2018, VOL. 2}

Lazaruk, W. (2007). Linguistic, academic, and cognitive benefits of French immersion. Canadian Modern Language Review, 63(5), 605-627.

Learning Disabilities Association of Ontario (2018, February). Learning Disabilities Statistics: Some recent Canadian sources for statistics on learning disabilities. Retrieved from http://www.ldao.ca/introduction-to-ldsadhd/articles/about-lds/learning-disabilitiesstatistics/

Lyon, G. R., Fletcher, J. M., Shaywitz, S. E., Shaywitz, B. A., Torgeson, J. K., Wood, F. B., et al. (2001). Rethinking learning disabilities. In C. E. Finn, Jr., A. J. Rotherham, \& C. R. Hokanson, Jr. (Eds.). Rethinking special education for a new century (pp. 259-287). Washington, DC: Thomas B. Fordham Foundation \& The Progressive Policy Institute.

Mady, C., \& Arnett, K. (2009). Inclusion in French immersion in Canada: One parent's perspective. Exceptionality Education International, 19(2), 37-49.

Mady, C., \& Black, G. (2012). Access to French as a second official language programs in English dominant Canada. Alberta Journal of Educational Research, 57(4), 498-501.

Ontario Ministry of Education (2017). Education Facts, 2016-2017 (Preliminary). Retrieved from: http:/www.edu.gov.on.ca/eng/educationFacts.html\#note1

Ontario Ministry of Education. (2013). The Ontario curriculum: French as a second language. Retrieved from: http://www.edu.gov.on.ca/eng/curriculum/elementary/fs118curr.pdf

Ontario Public School Boards' Association (2018). Meeting Labour Markets Needs for French as a Second Language Instruction in Ontario: Understanding Perspectives Regarding the French as a Second language Teacher Labour Market Issue, Retrieved from http://www.opsba.org/SiteCollectionDocuments/FSLsummary_INTERACTIVE.pdf

Paradis, M. (2004). A neurolinguistic theory of bilingualism. Amsterdam: John Benjamins Publishing Company.

Statistics Canada (2017a). Canadian Survey on Disability, 2017 in The Daily. Retrieved from https://www150.statcan.gc.ca/n1/en/daily-quotidien/181128/dq181128aeng.pdf?st=BWYUD8-e 


\section{ACTES DU SJPD-JPDS PROCEEDINGS, 2018, VOL. 2}

Statistics Canada (2017b). Table 477-0027 - Enrolments in French immersion programs, public elementary and secondary schools, Canada, CANSIM (database). Retrieved from https://www150.statcan.gc.ca/n1/daily-quotidien/171103/cg-c001-eng.htm

Swain, M. (1974). French Immersion Programs Across Canada: Research Findings. Canadian Modern Language Review, 31(2), 117-129.

Turnbull, M., Lapkin, S., \& Hart, D. (2001). Grade 3 immersion students' performance in literacy and mathematics: Province-wide results from Ontario (1998-99). Canadian Modern Language Review, 58(1), 9-26.

Wise, N. (2012). Access to special education for exceptional students in French immersion programs: An equity issue. Canadian Journal of Applied Linguistics, 14(1), 177-193. 